4

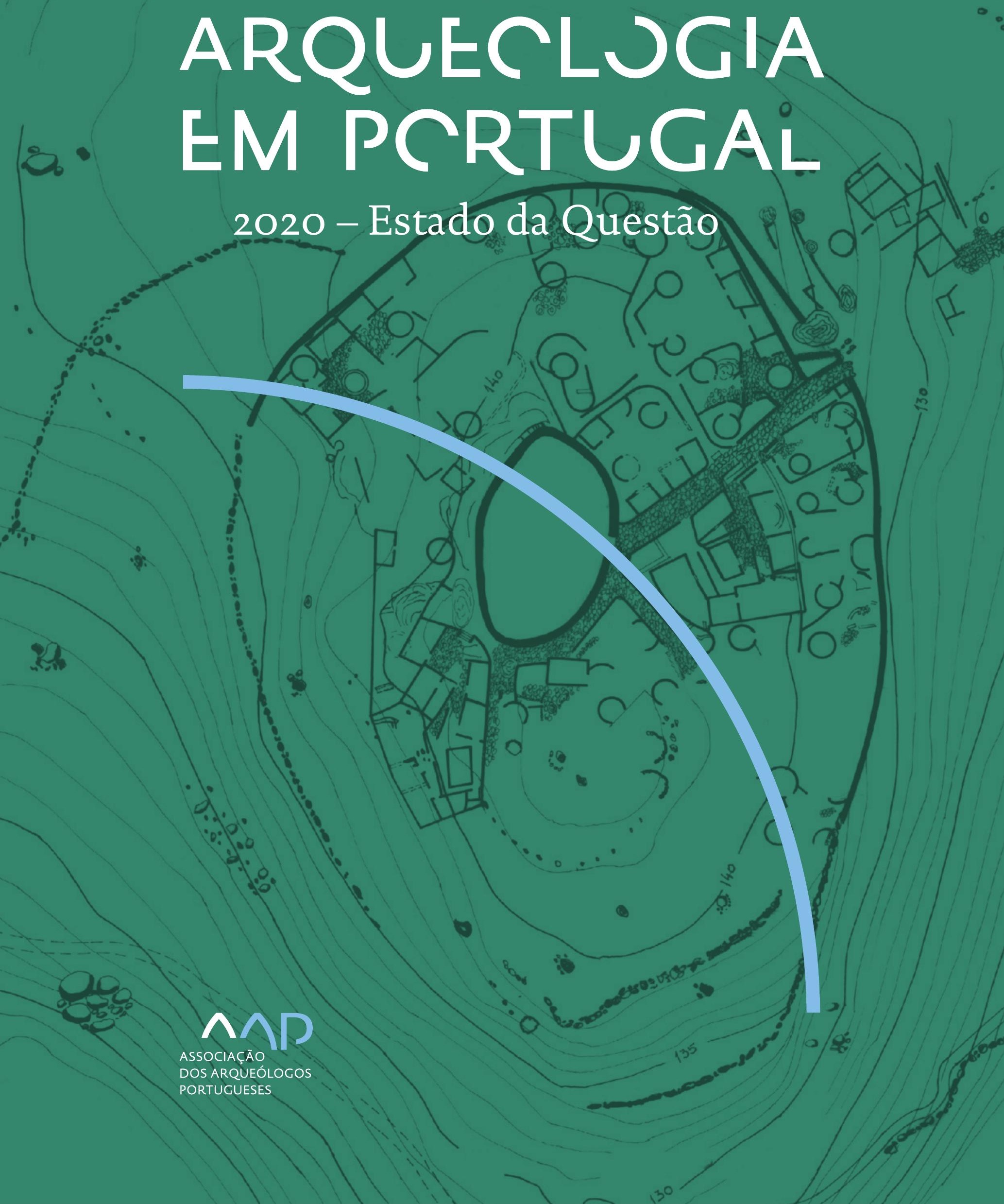


Coordenação editorial: José Morais Arnaud, César Neves e Andrea Martins Design gráfico: Flatland Design

AAP - ISBN: 978-972-9451-89-8

CITCEM - ISBN: 978-989-8970-25-1

Associação dos Arqueólogos Portugueses e CITCEM

Lisboa, 2020

O conteúdo dos artigos é da inteira responsabilidade dos autores. Sendo assim a Associação dos Arqueólogos Portugueses declina qualquer responsabilidade por eventuais equívocos ou questões de ordem ética e legal.

Desenho de capa:

Planta do castro de Monte Mozinho (Museu Municipal de Penafiel).

\section{$\hat{\wedge} \mathrm{P}$}

DOS ARQUEÓLOGOS PORTUGUESES

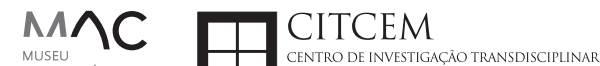
MUSEU
ARQUELLÓGICO
DO CARMO
U.PORTO

FLUP FACULDADE DE LETRAS
UNIVERSIDADE DO PORTO

Apoio

EC para a Ciência 


\section{Índice}

15 Prefácio

José Morais Arnaud

\section{Historiografia e Teoria}

17 Território, comunidade, memória e emoção: a contribuição da história da arqueologia (algumas primeiras e breves reflexões)

Ana Cristina Martins

25 Como descolonizar a arqueologia portuguesa?

Rui Gomes Coelho

41 Arqueologia e Modernidade: uma revisitação pessoal e breve de alguns aspetos da obra homónima de Julian Thomas de 2004

Vítor Oliveira Jorge

57 Dados para a História das Mulheres na Arqueologia portuguesa, dos finais do século XIX aos inícios do século XX: números, nomes e tabelas

Filipa Dimas / Mariana Diniz

73 Retractos da arqueologia portuguesa na imprensa: (in)visibilidades no feminino

Catarina Costeira / Elsa Luís

85 Arqueologia e Arqueólogos no Norte de Portugal Jacinta Bugalhão

101 Vieira Guimarães (1864-1939) e a arqueologia em Tomar: uma abordagem sobre o território e as gentes

João Amendoeira Peixoto / Ana Cristina Martins

115 Os memoráveis? A arqueologia algarvia na imprensa nacional e regional na presente centúria (2001-2019): características, visões do(s) passado(s) e a arqueologia

enquanto marca

Frederico Agosto / João Silva

129 A Evolução da Arqueologia Urbana e a Valorização Patrimonial no Barlavento Algarvio: Os casos de Portimão e Silves

Artur Mateus / Diogo Varandas / Rafael Boavida

\section{Gestão, Valorização e Salvaguarda do Património}

145 O Caderno Reivindicativo e as condições de trabalho em Arqueologia Miguel Rocha / Liliana Matias Carvalho / Regis Barbosa / Mauro Correia / Sara Simões / Jacinta Bugalhão / Sara Brito / Liliana Veríssimo Carvalho / Richard Peace / Pedro Peça / Cézer Santos

155 Os Estudos de Impacte Patrimonial como elemento para uma estratégia sustentável de minimização de impactes no âmbito de reconversões agrícolas Tiago do Pereiro

165 Salvaguarda de Património arqueológico em operações florestais: gestão e sensibilização Filipa Bragança / Gertrudes Zambujo / Sandra Lourenço / Belém Paiva / Carlos Banha / Frederico Tatá Regala / Helena Moura / Jacinta Bugalhão / João Marques / José Correia / Pedro Faria / Samuel Melro

179 Os valores do Património: uma investigação sobre os Sítios Pré-históricos de Arte Rupestre do Vale do Rio Côa e de Siega Verde José Paulo Francisco 
189 Conjugando recursos arqueológicos e naturais para potenciar as visitas ao Geoparque Litoral de Viana do Castelo (Noroeste de Portugal)

Hugo A. Sampaio / Ana M.S. Bettencourt / Susana Marinho / Ricardo Carvalhido

203 Áreas de Potencial Arqueológico na Região do Médio Tejo: Modelo Espacial Preditivo Rita Ferreira Anastácio / Ana Filipa Martins / Luiz Oosterbeek

223 Património Arqueológico e Gestão Territorial: O contributo da Arqueologia para a revisão do PDM de Avis

Ana Cristina Ribeiro

237 A coleção arqueológica do extinto Museu Municipal do Porto - Origens, Percursos e Estudos

Sónia Couto

251 Valpaços - uma nova carta arqueológica

Pedro Pereira / Maria de Fátima Casares Machado

263 Arqueologia na Cidade de Peniche

Adriano Constantino / Luís Rendeiro

273 Arqueologia Urbana: a cidade de Lagos como caso de Estudo Cátia Neto

285 Estratégias de promoção do património cultural subaquático nos Açores. O caso da ilha do Faial

José Luís Neto / José Bettencourt / Luís Borges / Pedro Parreira

297 Carta Arqueológica da Cidade Velha: Uma primeira abordagem

Jaylson Monteiro / Nireide Tavares / Sara da Veiga / Claudino Ramos / Edson Brito /

Carlos Carvalho / Francisco Moreira / Adalberto Tavares

311 Antropologia Virtual: novas metodologias para a análise morfológica e funcional Ricardo Miguel Godinho / Célia Gonçalves

\section{Didáctica da Arqueologia}

327 Como os projetos de Arqueologia podem contribuir para uma comunidade culturalmente mais consciente Alexandra Figueiredo / Claúdio Monteiro / Adolfo Silveira / Ricardo Lopes

337 Educação Patrimonial - Um cidadão esclarecido é um cidadão ativo! Ana Paula Almeida

351 A aproximação da Arqueologia à sala de aula: um caso de estudo no $3^{\circ}$ ciclo do Ensino Básico Luís Serrão Gil

363 Arqueologia 3.o - Pensar e comunicar a Arqueologia para um futuro sustentável Mónica Rolo

377 “Conversa de Arqueólogos" - Divulgar a Arqueologia em tempos de Pandemia Diogo Teixeira Dias

389 Escola Profissional de Arqueologia: desafios e oportunidades Susana Nunes / Dulcineia Pinto / Júlia Silva / Ana Mascarenhas

399 Os Museus de Arqueologia e os Jovens: a oferta educativa para o público adolescente Beatriz Correia Barata / Leonor Medeiros

411 O museu universitário como mediador entre a ciência e a sociedade: o exemplo da secção de arqueologia no Museu de História Natural e da Ciência da Universidade do Porto (MHNC-UP)

Rita Gaspar 
421 Museu de Lanifícios: Real Fábrica de Panos. Atividades no âmbito da Arqueologia Beatriz Correia Barata / Rita Salvado

427 Arqueologia Pública e o caso da localidade da Mata (Torres Novas) Cláudia Manso / Ana Rita Ferreira / Cristiana Ferreira / Vanessa Cardoso Antunes

431 Do sítio arqueológico ao museu: um percurso (também) didático Lídia Fernandes

447 Estão todos convidados para a Festa! E para dançar também... O projecto do Serviço Educativo do Museu Arqueológico do Carmo na $5^{\underline{a}}$ Edição da Festa da Arqueologia Rita Pires dos Santos

459 O “Clã de Carenque”, um projeto didático de arqueologia Eduardo Gonzalez Rocha

469 Mediação cultural: peixe que puxa carroça nas Ruínas Romanas de Troia Inês Vaz Pinto / Ana Patrícia Magalhães / Patrícia Brum / Filipa Santos

481 Didática Arqueológica, experiências do Projeto Mértola Vila Museu Maria de Fátima Palma / Clara Rodrigues / Susana Gómez / Lígia Rafael

\section{Arte Rupestre}

497 Os inventários de arte rupestre em Portugal Mila Simões de Abreu

513 O projeto FIRST-ART - conservação, documentação e gestão das primeiras manifestações de arte rupestre no Sudoeste da Península Ibérica: as grutas do Escoural e Maltravieso Sara Garcês / Hipólito Collado / José Julio García Arranz / Luiz Oosterbeek / António Carlos Silva / Pierluigi Rosina / Hugo Gomes / Anabela Borralheiro Pereira / George Nash / Esmeralda Gomes / Nelson Almeida / Carlos Carpetudo

523 Trabalhos de documentação de arte paleolítica realizados no âmbito do projeto PalæoCôa André Tomás Santos / António Fernando Barbosa / Luís Luís / Marcelo Silvestre / Thierry Aubry

537 Imagens fantasmagóricas, silhuetas elusivas: as figuras humanas na arte do Paleolítico Superior da região do Côa Mário Reis

$55^{1}$ Os motivos zoomórficos representados nas placas de tear de Vila Nova de São Pedro (Azambuja, Portugal) Andrea Martins / César Neves / José M. Arnaud / Mariana Diniz

571 Arte Rupestre do Monte de Góios (Lanhelas, Caminha). Síntese dos resultados dos trabalhos efectuados em 2007-2009 Mário Varela Gomes

599 Gravuras rupestres de barquiformes no Monte de S. Romão, Guimarães, Noroeste de Portugal Daniela Cardoso

613 Círculos segmentados gravados na Bacia do Rio Lima (Noroeste de Portugal): contributos para o seu estudo Diogo Marinho / Ana M.S. Bettencourt / Hugo Aluai Sampaio

631 Equídeos gravados no curso inferior do Rio Mouro, Monção (NW Portugal). Análise preliminar Coutinho, L.M. / Bettencourt, A.M.S / Sampaio, Hugo A.S

645 Paletas na Arte Rupestre do Noroeste de Portugal. Inventário preliminar Bruna Sousa Afonso / Ana M. S. Bettencourt / Hugo A. Sampaio 


\section{Pré-História}

661 O projeto Miño/Minho: balanço de quatro anos de trabalhos arqueológicos Sérgio Monteiro-Rodrigues / João Pedro Cunha-Ribeiro / Eduardo Méndez-Quintas / Carlos Ferreira / Pedro Xavier / José Meireles / Alberto Gomes / Manuel Santonja / Alfredo Pérez-González

677 A ocupação paleolítica da margem esquerda do Baixo Minho: a indústria lítica do sítio de Pedreiras 2 (Monção, Portugal) e a sua integração no contexto regional Carlos Ferreira / João Pedro Cunha-Ribeiro / Sérgio Monteiro-Rodrigues / Eduardo Méndez-Quintas / Pedro Xavier / José Meireles / Alberto Gomes / Manuel Santonja / Alfredo Pérez-González

693 O sítio acheulense do Plistocénico médio da Gruta da Aroeira Joan Daura / Montserrat Sanz / Filipa Rodrigues / Pedro Souto / João Zilhão

703 As sociedades neandertais no Barlavento algarvio: modelos preditivos com recurso aos SIG

Daniela Maio

715 A utilização de quartzo durante o Paleolítico Superior no território dos vales dos rios Vouga e Côa

Cristina Gameiro / Thierry Aubry / Bárbara Costa / Sérgio Gomes / Luís Luís / Carmen Manzano / André Tomás Santos

733 Uma perspetiva diacrónica da ocupação do concheiro do Cabeço da Amoreira (Muge, Portugal) a partir da tecnologia lítica Joana Belmiro / João Cascalheira / Célia Gonçalves

745 Novos dados sobre a Pré-história Antiga no concelho de Palmela. A intervenção arqueológica no sítio do Poceirão I

Michelle Teixeira Santos

757 Problemas em torno de Datas Absolutas Pré-Históricas no Norte do Alentejo Jorge de Oliveira

771 Povoamento pré-histórico nas áreas montanhosas do NO de Portugal: o Abrigo 1 de Vale de Cerdeira Pedro Xavier / José Meireles / Carlos Alves

783 Apreciação do povoamento do Neolítico Inicial na Baixa Bacia do Douro. A Lavra I (Serra da Aboboreira) como caso de estudo Maria de Jesus Sanches

797 O Processo de Neolitização na Plataforma do Mondego: os dados do Sector C do Outeiro dos Castelos de Beijós (Carregal do Sal)

João Carlos de Senna-Martinez / José Manuel Quintã Ventura / Andreia Carvalho / Cíntia Maurício

823 Novos trabalhos na Lapa da Bugalheira (Almonda, Torres Novas) Filipa Rodrigues / Pedro Souto / Artur Ferreira / Alexandre Varanda / Luís Gomes / Helena Gomes / João Zilhão

837 A pedra polida e afeiçoada do sítio do Neolítico médio da Moita do Ourives (Benavente, Portugal)

César Neves

857 Casal do Outeiro (Encarnação, Mafra): novos contributos para o conhecimento do povoamento do Neolítico final na Península de Lisboa.

Cátia Delicado / Carlos Maneira e Costa / Marta Miranda / Ana Catarina Sousa

873 Stresse infantil, morbilidade e mortalidade no sítio arqueológico do Neolítico Final/ Calcolítico ( $4^{\circ}$ e $3^{\circ}$ milénio a.C.) do Monte do Carrascal 2 (Ferreira do Alentejo, Beja) Liliana Matias de Carvalho / Sofia N. Wasterlain 
885 Come together: O Conjunto Megalítico das Motas (Monção, Viana do Castelo) e as expressões Campaniformes do Alto Minho Ana Catarina Basílio / Rui Ramos

899 Trabalhos arqueológicos no sítio Calcolítico da Pedreira do Poio Carla Magalhães / João Muralha / Mário Reis / António Batarda Fernandes

913 O sítio arqueológico de Castanheiro do Vento. Da arquitectura do sítio à arquitectura de um território João Muralha Cardoso

925 Estudo zooarqueológico das faunas do Calcolítico final de Vila Nova de São Pedro (Azambuja, Portugal): Campanhas de 2017 e 2018 Cleia Detry / Ana Catarina Francisco / Mariana Diniz / Andrea Martins / César Neves / José Morais Arnaud

943 As faunas depositadas no Museu Arqueológico do Carmo provenientes de Vila Nova de São Pedro (Azambuja): as campanhas de 1937 a 1967 Ana Catarina Francisco / Cleia Detry / César Neves / Andrea Martins / Mariana Diniz / José Morais Arnaud

959 Análise funcional de material lítico em sílex do castro de Vila Nova de S. Pedro (Azambuja, Portugal): uma primeira abordagem Rafael Lima

971 O recinto da Folha do Ouro 1 (Serpa) no contexto dos recintos de fossos calcolíticos alentejanos

António Carlos Valera / Tiago do Pereiro / Pedro Valério / António M. Monge Soares

\section{Proto-História}

987 Produção de sal marinho na Idade do Bronze do noroeste Português. Alguns dados para uma reflexão

Ana M. S. Bettencourt / Sara Luz / Nuno Oliveira / Pedro P. Simões / Maria Isabel C. Alves / Emílio Abad-Vidal

1001 A estátua-menir do Pedrão ou de São Bartolomeu do Mar (Esposende, noroeste de Portugal) no contexto arqueológico da fachada costeira de entre os rios Neiva e Cávado Ana M. S. Bettencourt / Manuel Santos-Estévez / Pedro Pimenta Simões / Luís Gonçalves

1015 O Castro do Muro (Vandoma/Baltar, Paredes) - notas para uma biografia de ocupação da Idade do Bronze à Idade Média

Maria Antónia D. Silva / Ana M. S. Bettencourt / António Manuel S. P. Silva / Natália Félix

1031 Do Bronze Final à Idade Média - continuidades e hiatos na ocupação de Povoados em Oliveira de Azeméis João Tiago Tavares / Adriaan de Man

1041 As faunas do final da Idade do Bronze no Sul de Portugal: leituras desde o Outeiro do Circo (Beja)

Nelson J. Almeida / Íris Dias / Cleia Detry / Eduardo Porfírio / Miguel Serra

1055 A Espada do Monte das Oliveiras (Serpa) - uma arma do Bronze Pleno do Sudoeste Rui M. G. Monge Soares / Pedro Valério / Mariana Nabais / António M. Monge Soares

1065 São Julião da Branca (Albergaria-a-Velha) - Investigação e valorização de um povoado do Bronze Final

António Manuel S. P. Silva / Paulo A. P. Lemos / Sara Almeida e Silva / Edite Martins de Sá

1083 Do castro de S. João ao Mosteiro de Santa Clara: notícia de uma intervenção arqueológica, em Vila do Conde Rui Pinheiro 
1095 O castro de Ovil (Espinho), um quarto de século de investigação - resultados e questões em aberto

Jorge Fernando Salvador / António Manuel S. P. Silva

1111 O Castro de Salreu (Estarreja), um povoado proto-histórico no litoral do Entre Douro e Vouga

Sara Almeida e Silva / António Manuel S. P. Silva / Paulo A. P. Lemos / Edite Martins de Sá

1127 Castro de Nossa Senhora das Necessidades (Sernancelhe): uma primeira análise artefactual Telma Susana O. Ribeiro

${ }_{1141}$ A cividade de Bagunte. O estado atual da investigação Pedro Brochado de Almeida

1153 Zoomorfos na cerâmica da Idade do Ferro no NW Peninsular: inventário, cronologias e significado Nuno Oliveira / Cristina Seoane

1163 Vasos gregos em Portugal: diferentes maneiras de contar a história do intercâmbio cultural na Idade do Ferro

Daniela Ferreira

1175 Os exotica da necrópole da Idade do Ferro do Olival do Senhor dos Mártires (Alcácer do Sal) no seu contexto regional

Francisco B. Gomes

\section{Antiguidade Clássica e Tardia}

1191 O uso de madeira como combustível no sítio da Quinta de Crestelos (Baixo Sabor): da Idade do Ferro à Romanização Filipe Vaz / João Tereso / Sérgio Simões Pereira / José Sastre / Javier Larrazabal Galarza / Susana Cosme / José António Pereira / Israel Espi

1207 Cultivos de Época Romana no Baixo Sabor: continuidade em tempos de mudança? João Pedro Tereso / Sérgio Simões Pereira / Filipe Santos / Luís Seabra / Filipe Vaz

1221 A casa romana na Hispânia: aplicação dos modelos itálicos nas províncias ibéricas Fernanda Magalhães / Diego Machado / Manuela Martins

1235 As pinturas murais romanas da Rua General Sousa Machado, n. ${ }^{5}$ 1, Chaves José Carvalho

1243 Trás do Castelo (Vale de Mir, Pegarinhos, Alijó) - Uma exploração agrícola romana do Douro

Tony Silvino / Pedro Pereira

1255 A sequência de ocupação no quadrante sudeste de Bracara Augusta: as transformações de uma unidade doméstica Lara Fernandes / Manuela Martins

1263 Os Mosaicos com decoração geométrica e geométrico-vegetalista dos sítios arqueológicos da área do Conuentus Bracaraugustanus. Novas abordagens quanto à conservação, restauro, decoração e datação Maria de Fátima Abraços / Licínia Wrench

1277 “Casa Romana” do Castro de São Domingos (Cristelos, Lousada): Escavação, Estudo e Musealização Paulo André de P. Lemos

1291 A arqueobotânica no Castro de Guifões (Matosinhos, Noroeste de Portugal): O primeiro estudo carpológico

Luís Seabra / Andreia Arezes / Catarina Magalhães / José Varela / João Pedro Tereso 
1305 Um Horreum Augustano na Foz do Douro (Monte do Castelo de Gaia, Vila Nova de Gaia) Rui Ramos

1311 Ponderais romanos na Lusitânia: padrões, formas, materiais e contextos de utilização Diego Barrios Rodríguez

1323 Um almofariz centro-itálico na foz do Mondego

Marco Penajoia

1335 Estruturas romanas de Carnide - Lisboa Luísa Batalha / Mário Monteiro / Guilherme Cardoso

1347 O contexto funerário do sector da "necrópole NO" da Rua das Portas de S. Antão (Lisboa): o espaço, os artefactos, os indivíduos e a sua interconectividade na interpretação do passado Sílvia Loja, José Carlos Quaresma, Nelson Cabaço, Marina Lourenço, Sílvia Casimiro, Rodrigo Banha da Silva, Francisca Alves-Cardoso

${ }_{1361}$ Povoamento em época Romana na Amadora - resultados de um projeto pluridisciplinar Gisela Encarnação / Vanessa Dias

1371 A Arquitectura Residencial em Mirobriga (Santiago do Cacém): contributo a partir de um estudo de caso Filipe Sousa / Catarina Felício

${ }_{1385}$ O fim do ciclo. Saneamento e gestão de resíduos nos edifícios termais de Mirobriga (Santiago do Cacém)

Catarina Felício / Filipe Sousa

1399 Balsa, Topografia e Urbanismo de uma Cidade Portuária Vítor Silva Dias / João Pedro Bernardes / Celso Candeias / Cristina Tété Garcia

1413 No Largo das Mouras Velhas em Faro (2017): novas evidências da necrópole norte de Ossonoba e da sua ocupação medieval Ricardo Costeira da Silva / Paulo Botelho / Fernando Santos / Liliana Nunes

1429 Instrumentos de pesca recuperados numa fábrica de salga em Ossonoba (Faro) Inês Rasteiro / Ricardo Costeira da Silva / Paulo Botelho

1439 A Necrópole Romana do Eirô, Duas Igrejas (Penafiel): intervenção arqueológica de 2016 Laura Sousa / Teresa Soeiro

1457 Ritual, descarte ou afetividade? A presença de Canis lupus familiaris na Necrópole Noroeste de Olisipo (Lisboa)

Beatriz Calapez Santos / Sofia Simões Pereira / Rodrigo Banha da Silva / Sílvia Casimiro / Cleia Detry / Francisca Alves Cardoso

1467 Dinâmicas económicas em Bracara na Antiguidade Tardia Diego Machado / Manuela Martins / Fernanda Magalhães / Natália Botica

1479 Cerâmicas e Vidros da Antiguidade Tardia do Edifício sob a Igreja do Bom Jesus (Vila Nova de Gaia) Joaquim Filipe Ramos

1493 Novos contributos para a topografia histórica de Mértola no período romano e na Antiguidade Tardia Virgílio Lopes

\section{8. Época Medieval}

1511 Cerâmicas islâmicas no Garb setentrional "português": algumas evidências e incógnitas Constança dos Santos / Helena Catarino / Susana Gómez / Maria José Gonçalves / Isabel Inácio / Gonçalo Lopes / Jacinta Bugalhão / Sandra Cavaco / Jaquelina Covaneiro / Isabel Cristina Fernandes / Ana Sofia Gomes 
1525 Contributo para o conhecimento da cosmética islâmica, em Silves, durante a Idade Média Rosa Varela Gomes

1537 Yábura e o seu território - uma análise histórico-arqueológica de Évora entre os séculos VIII-XII José Rui Santos

1547 A encosta sul do Castelo de Palmela - resultados preliminares da escavação arqueológica Luís Filipe Pereira / Michelle Teixeira Santos

1559 A igreja de São Lourenço (Mouraria, Lisboa): um conjunto de silos e de cerâmica medieval islâmica

Andreia Filipa Moreira Rodrigues

1571 O registo material de movimentações populacionais no Médio Tejo, durante os séculos XII-XIII. Dois casos de "sunken featured buildings", nos concelhos de Cartaxo e Torres Novas Marco Liberato / Helena Santos / Nuno Santos

1585 O nordeste transmontano nos alvores da Idade média. Notas para reflexão Ana Maria da Costa Oliveira

1601 Sepulturas escavadas na rocha do Norte de Portugal e do Vale do Douro: primeiros resultados do Projecto SER-NPVD

Mário Jorge Barroca / César Guedes / Andreia Arezes / Ana Maria Oliveira

1619 "Portucalem Castrum Novum" entre o Mediterrâneo e o Atlântico: o estudo dos materiais cerâmicos alto-medievais do arqueossítio da rua de D. Hugo, nํ. 5 (Porto) João Luís Veloso

1627 A Alta Idade Média na fronteira de Lafões: notas preliminares sobre a Arqueologia no Concelho de Vouzela

Manuel Luís Real / Catarina Tente

1641 Um conjunto cerâmico medieval fora de portas: um breve testemunho aveirense Susana Temudo

${ }_{1651}$ Os Lóios do Porto: uma perspetiva integrada no panorama funerário da Baixa Idade Média à Época Moderna em meios urbanos em Portugal

Ana Lema Seabra

1659 O Caminho Português Interior de Santiago como eixo viário na Idade Média Pedro Azevedo

1665 Morfologia Urbana: Um exercício em torno do Castelo de Ourém André Donas-Botto / Jaqueline Pereira

1677 Intervenção arqueológica na Rua Marquês de Pombal/Largo do Espírito Santo (Bucelas, Loures)

Florbela Estêvão / Nathalie Antunes-Ferreira / Dário Ramos Neves / Inês Lisboa

1691 O Cemitério Medieval do Poço do Borratém e a espacialidade funerária na cidade de Lisboa Inês Belém / Vanessa Filipe / Vasco Noronha Vieira / Sónia Ferro / Rodrigo Banha da Silva

1705 Um Espaço Funerário Conventual do séc. XV em Lisboa: o caso do Convento de São Domingos da Cidade Sérgio Pedroso / Sílvia Casimiro / Rodrigo Banha da Silva / Francisca Alves Cardoso

\section{9. Época Moderna e Contemporânea}

1721 Arqueologia Moderna em Portugal: algumas reflexões críticas em torno da quantificação de conjuntos cerâmicos e suas inferências históricas e antropológicas Rodrigo Banha da Silva / André Bargão / Sara da Cruz Ferreira

1733 Faianças de dois contextos entre os finais do século XVI e XVIII do Palácio dos Condes de Penafiel, Lisboa

Martim Lopes / Tomás Mesquita 
1747 Um perfil de consumo do século XVIII na foz do Tejo: O caso do Mercado da Ribeira, Lisboa Sara da Cruz Ferreira / Rodrigo Banha da Silva / André Bargão

1761 Os Cachimbos dos Séculos XVII e XVIII do Palácio Mesquitela e Convento dos Inglesinhos (Lisboa)

Inês Simão / Marina Pinto / João Pimenta / Sara da Cruz Ferreira / André Bargão / Rodrigo Banha da Silva

1775 "Tomar os fumos da erua que chamão em Portugal erua sancta». Estudo de Cachimbos provenientes da Rua do Terreiro do Trigo, Lisboa

Miguel Martins de Sousa / José Pedro Henriques / Vanessa Galiza Filipe

1787 Cachimbos de Barro Caulínitico da Sé da Cidade Velha (República de Cabo Verde)

Rodrigo Banha da Silva / João Pimenta / Clementino Amaro

1801 Algumas considerações sobre espólio não cerâmico recuperado no Largo de Jesus (Lisboa) Carlos Boavida

1815 Adereços de vidro, dos séculos XVI-XVIII, procedentes do antigo Convento de Santana de Lisboa (anéis, braceletes e contas)

Joana Gonçalves / Rosa Varela Gomes / Mário Varela Gomes

1837 Da ostentação, luxo e poder à simplicidade do uso quotidiano: arqueologia e simbologia de joias e adornos da Idade Moderna Portuguesa Jéssica Iglésias

1849 Os amuletos em Portugal - dos objetos às superstições: o coral vermelho Alexandra Vieira

1865 Cerâmicas de Vila Franca de Xira nos séculos XV e XVI Eva Pires

1879 «Não passa por teu o que me pertence». Marcas de individualização associadas a faianças do Convento de Nossa Senhora de Aracoeli, Alcácer do Sal Catarina Parreira / Íris Fragoso / Miguel Martins de Sousa

1891 Cerâmica de Leiria: alguns focos de produção

Jaqueline Pereira / André Donas-Botto

1901 Os Fornos na Rua da Biquinha, em Óbidos Hugo Silva / Filipe Oliveira

1909 A casa de Pêro Fernandes, contador dos contos de D. Manuel I: o sítio arqueológico da Silha do Alferes, Seixal (século XVI) Mariana Nunes Ferreira

1921 O Alto da Vigia (Sintra) e a vigilância e defesa da costa Alexandre Gonçalves / Sandra Santos

1937 O contexto da torre sineira da Igreja de Santa Maria de Loures Paulo Calaveira / Martim Lopes

1949 A Necrópole do Hospital Militar do Castelo de São Jorge e as práticas funerárias na Lisboa de Época Moderna Susana Henriques / Liliana Matias de Carvalho / Ana Amarante / Sofia N. Wasterlain

1963 SAND - Sarilhos Grandes Entre dois Mundos: o adro da Igreja e a Paleobiologia dos ossos humanos recuperados

Paula Alves Pereira / Roger Lee Jesus / Bruno M. Magalhães

1975 Expansão urbana da vila de Cascais no século XVII e XVIII: a intervenção arqueológica na Rua da Vitória no 15 a 17

Tiago Pereira / Vanessa Filipe

1987 Novos dados para o conhecimento do Urbanismo de Faro em época Moderna Ana Rosa 
1995 Um exemplo de Arqueologia Urbana em Alcoutim: o Antigo Edifício dos CTT Marco Fernandes / Marta Dias / Alexandra Gradim / Virgílio Lopes / Susana Gómez Martínez

2007 Palácio dos Ferrazes (Rua das Flores/Rua da Vitória, Porto): a cocheira de Domingos Oliveira Maia

Francisco Raimundo

2021 As muitas vidas de um edifício urbano: História, Arqueologia e Antropologia no antigo Recreatório Paroquial de Penafiel Helena Bernardo / Jorge Sampaio / Marta Borges

2035 O convento de Nossa Senhora da Esperança de Ponta Delgada: o contributo da arqueologia para o conhecimento de um monumento identitário João Gonçalves Araújo / N’Zinga Oliveira

2047 Arqueologia na ilha do Corvo... em busca da capela de Nossa Senhora do Rosário Tânia Manuel Casimiro / José Luís Neto / Luís Borges / Pedro Parreira

2059 Perdidos à vista da Costa. Trabalhos arqueológicos subaquáticos na Barra do Tejo Jorge Freire / José Bettencourt / Augusto Salgado

2071 Arqueologia marítima em Cabo Verde: enquadramento e primeiros resultados do projecto CONCHA

José Bettencourt / Adilson Dias / Carlos Lima / Christelle Chouzenoux / Cristóvão Fonseca / Dúnia Pereira / Gonçalo Lopes / Inês Coelho / Jaylson Monteiro / José Lima / Maria Eugénia Alves / Patrícia Carvalho / Tiago Silva

2085 Trabalhos arqueológicos na Cidade Velha (Ribeira Grande de Santiago, Cabo Verde): reflexões sobre um projecto de investigação e divulgação patrimonial André Teixeira / Jaylson Monteiro / Mariana Mateus / Nireide Tavares / Cristovão Fonseca / Gonçalo C. Lopes / Joana Bento Torres / Dúnia Pereira / André Bargão / Aurélie Mayer / Bruno Zélie / Carlos Lima / Christelle Chouzenoux / Inês Henriques / Inês Pinto Coelho / José Lima / Patrícia Carvalho / Tiago Silva

2103 A antiga fortificação de Quelba / Khor Kalba (E.A.U.). Resultados de quatro campanhas de escavações, problemáticas e perspectivas futuras Rui Carita / Rosa Varela Gomes / Mário Varela Gomes / Kamyar Kamyad

2123 Colónias para homens novos: arqueologia da colonização agrária fascista no noroeste ibérico Xurxo Ayán Vila / José Mạ . Señorán Martín 


\title{
A CASA DE PÊRO FERNANDES, CONTADOR DOS CONTOS DE D. MANUEL I: O SÍTIO ARQUEOLÓGICO DA SILHA DO ALFERES, SEIXAL (SÉCULO XVI)
}

\author{
Mariana Nunes Ferreira ${ }^{1}$
}

\begin{abstract}
RESUMO
O sítio arqueológico da Silha do Alferes foi descoberto em 1984. Escavações não autorizadas foram desenvolvidas por detectoristas e o local pilhado. Nesse mesmo ano, o Ecomuseu do Seixal procedeu à recolha, lavagem e armazenamentos dos materiais.

O espólio sobrevivente, do qual não contam metais, encontra-se bem preservado. É composto por várias peças completas tais como taças, pratos, púcaros, testos, fogareiros entre outros, característicos de um contexto doméstico. A tipologia dos artefactos corresponde a um deposição da primeira metade do século XVI. Este trabalho pretende dar a conhecer este sítio arqueológico debatendo a sua importância para o conhecimento da zona do Seixal nesta época.

Palavras-chave: Idade Moderna, Cultura Material, Contexto Doméstico, Seixal.
\end{abstract}

\begin{abstract}
The archaeological site of Silha do Alferes was discovered in 1984. Illegal excavations were made by metal detector owners and in that same year the Museum of Seixal recorded the site and recovered the material culture left behind.

The collection is well preserved with several complete objects such as bowls, plates, cups, lids, and braziers among others. This is the typical collection of a domestic context. The typology of the artefacts corresponds to a first half of the $16^{\text {th }}$ century context formation. This paper aims to acknowledge this site debating its importance in the study of Seixal are.
\end{abstract}

Keywords: Early Modern Age, Material Culture, Domestic Context, Seixal.

\section{INTRODUÇÃO}

O sítio arqueológico da Silha do Alferes (CNS 37628 ) situa-se na margem esquerda do Rio Tejo, no município do Seixal pertencente à Península de Setúbal e à Área Metropolitana de Lisboa, a cerca de 10 quilómetros do núcleo urbano (Figura 1). Em 1984 foram realizadas escavações não autorizadas auxiliadas por detectores de metais tendo o sítio sido parcialmente destruído. O sítio foi assim ilegalmente escavado não havendo resultados dessa ação, nem qualquer registo de campo. Nesse mesmo ano, arqueólogos do Museu do Seixal dirigiram-se ao local. Foi reali- zada uma limpeza superficial do terreno e recolhidos os materiais arqueológicos ali deixados. Foram lavados, separados por tipologias e armazenados por mais de 30 anos.

O sítio encontra-se na área do Parque Industrial do Seixal mais propriamente no perímetro da empresa Extruplás, Reciclagem, Recuperação e Fabrico de Produtos Plásticos, Lda e devido ao aumento da zona de armazenamento de plásticos o sítio encontra-se em risco de ser tapado.

A Silha do Alferes não é o único contexto da Idade Moderna conhecido neste município. Em 2016 desenvolveram-se trabalhos arqueológicos na frente

1. FSCH; mariananunesferreira@hotmail.com 
ribeirinha do Seixal, no âmbito da remodelação da zona, tendo sido encontrados mais contextos desta época. Ainda que apenas sejam conhecidos os resultados preliminares foram identificados diversos contextos de aterro (McClelland et all, 2016) nomeadamente na Rua da República e no Largo da Igreja. No entanto, a Silha do Alferes é um sítio de elevada importância. Em primeiro lugar porque é possível atribuir um proprietário aos terrenos onde este sítio arqueológico foi formado no século XVI. Existe na Chancelaria de D. Manuel datado de 14 de Março de 1517 (TT/CHR/K/10/17-62V), a atribuição a a atribuição a pedro fernamdez comtador dos comtos $\mathrm{d}$ el Rey doaçom de hua quinta que se chama a torre queimada de sesmaria que esta no termo da villa d almada.

Pedro Fernandes ocupava um cargo na administração central que tinha como função fiscalizar e controlar as finanças públicas. Como funcionário do estado e detentor de uma teria uma posição de destaque nesta zona da margem sul do Tejo. É impossível dizer qual o tempo que Pedro Fernandes passou nesta quinta e o espólio aqui identificado poderá nunca ter tido uma relação direta com o seu proprietário, sendo apenas o resultado das muitas casas que ali se encontravam. É, no entanto, fundamental, compreender que este sítio, apesar de não ter sido alvo de uma escavação rigorosa, representa uma ocupação rural de Idade Moderna que, até então, não se conhecia para a zona do Seixal. Por tal, não pode ser ignorado.

Dada a ausência de uma escavação arqueológica efectuada por arqueólogos creditados leva a que a estratigrafia não seja segura. Em visita ao local surgem à superfície vestígios de muros que não conseguimos interpretar. No entanto com a análise dos materiais foi possível concluir que estamos perante uma coleção cronologicamente enquadrada na primeira metade do século XVI, sem qualquer objeto que seja datável quer de momentos anteriores quer de momentos posteriores.

O estudo foi assim efectuado única e exclusivamente em torno dos materiais ali identificados. Foi efectuada uma contabilização total dos fragmentos onde se considerou a sua forma, tipo de bordo e fundo, caracterização e coloração das pastas, o código de cores Munsell Soil Color Chart, tal como a dimensão, o tratamento de superfície e a caracterização dos elementos decorativos.

A contabilização dos objetos foi efectuada relativamente ao número total de fragmentos. Para o seu estudo foi realizada a contabilização através do número mínimo de indivíduos - NMI. Executou-se o desenho das peças mais completas ou que mostrassem detalhes importantes.

\section{A COLEÇÃO}

A ausência de estruturas arqueológicas que pudessem auxiliar na interpretação dos objetos identificados levou a que os mesmos tivessem de ser organizados de acordo com a sua funcionalidade.

Nos contextos arqueológicos do século XVI a maioria da cerâmica recuperada insere-se no grupo das loiças utilizadas na cozinha que tem como função a confecção de alimentos e o apoio a esta atividade.

Nos contextos da Idade Moderna as formas mais frequentes são as panelas (Casimiro, Boavida e Detry; 2017 p. 112) tal como acontece na Silha do Alferes (Figura 2). Estas peças são caracterizadas pela forma globular, um fundo plano, colo alto e duas asas verticais. No que diz respeito ao bordo este pode indicar cronologias diferentes sendo que um bordo subvertical, marcado por duas caneluras pode representar o século XVI, um bordo espessado e extrovertido o século XVII e um bordo de lábio de secção biselada o século XVIII (Gomes et al., 2013, p. 1059). As panelas, devido à função primordial que encontram dentro dos contextos habitacionais, são peças que são encontradas em contextos arqueológicos por todo o país, em todos os locais onde foram identificadas casas e ocupação doméstica. (Casimiro, Boavida e Detry, 2017, p. 113 ; Gomes et al., 2013, p. 1059.; Barbosa, Casimiro e Manaia, 2009, p. 123; Rodrigues et al., 2013, p. 866).

Sabemos pelos livros de receitas da época que as panelas estão associadas à cozedura de alimentos $\mathrm{e}$ produção de ensopados sejam eles carne, peixe ou até legumes (Casimiro, Boavida e Detry, 2017, p. 112). A segunda forma mais frequente neste contextos doméstico são os tachos, estes apresentam uma forma hemisférica com paredes altas, assentes em plano fundo com asas horizontais ou pegas triangulares (Casimiro, Boavida e Detry, 2017, p. 113) (Figura 2). É associado à confecção de refugados ou estufados nos livros de receitas. Tal como as panelas, os tachos são frequentemente encontrados em contextos domésticos (Fernandes e Carvalho, 2003, p. 233).

Outras das formas usada na cozinha é a frigideira, sendo esta usada para fritar, mas também são mencionadas como peças que podem ir ao forno. Estas 
são caracterizadas por ter uma forma hemisférica, paredes mais baixas e pegas triangulares ou um cabo tubular.

Os testos e tampas serviam para tapar as formas acima mencionadas. Os testos aqui estudados apresentam forma tronco cónica, um fundo plano, bordo semicircular ou bordo extrovertido com uma pega na parte superior (Figura 2). Tal como os tachos, panelas e frigideiras são peças frequentes nos contextos arqueológicos, sobretudo associados a contextos domésticos (Casimiro, Boavida e Detry, 2017, p. 114; Fernandes e Carvalho, 2003, p. 233; Gomes et al., 2013, p. 1059).

Os alguidares (Figura 3) tem como função ajudar na preparação da comida como por exemplo na preparação de enchidos como é referido no livro Arte da Cozinha de Domingos Rodrigues (Casimiro, Boavida e Detry, 2017, p. 115).

Uma peça fundamental para a vida dentro da cozinha é o fogareiro pois é este que permite ter um lume brando para a confecção dos alimentos (Figura 3). Esta é uma peça que aparece nos contextos domésticos desde a Idade Média (Casimiro, Boavida e Detry, 2017, p. 116) e por isso é uma peça com alguma expressão nos contextos modernos.

O cuscuzeiro (Figura 3) é uma peça menos frequente em contexto arqueológico mas são mencionados nos livros de receitas como no livro Arte da Cozinha. O consumo de cuscuz é introduzido na alimentação dos portugueses a partir dos finais do século XV (Casimiro, Boavida e Detry, 2017, p. 115; Gomes, Casimiro e Neto, 2017, p. 9) tendo sido encontrado dois fragmentos na Silha do Alferes.

O segundo grande grupo de estudo são as cerâmicas de servir à mesa, neste grupo é importante destacar a faiança que supera em número a cerâmica vidrada de chumbo. Os objetos encontrados fazem parte do serviço de mesa e são utlizados para servir e consumir os alimentos (Figura 4).

Os pratos em faiança possuem todos as mesmas características morfológicas tendo uma forma tronco cónica com fundo em ônfalo. Os pratos revestidos com vidrado de chumbo, podem também representar fundos anelares ou planos. O bordo é também na maioria das vezes semicircular, podendo existir bordos extrovertidos. O prato era a forma mais comum de servir à mesa (Casimiro, Boavida e Detry, 2017, p. 116).

As taças são peças com alguma expressão neste contexto, existindo taças em vidrado de chumbo e vi- drado estanífero. As suas formas correspondem a peças hemisféricas ou carenadas, assentes em fundo com pé anelar. Os objetos de servir à mesa são parcamente decorados. As peças em faiança apresentam a ocasional linha azul concêntrica junto ao bordo e as peças revestidas a vidrado de chumbo, verde ou amarelo, apresentam pequenas caneluras abaixo do bordo (Casimiro et al., 2018, p. 275) Destacam-se alguns fragmentos decorados a azul e manganês num estilo por norma reconhecido como Isabella Polychrome, muito possivelmente produzido na Andaluzia.

Neste grupo de louça de mesa podemos ainda incluir os púcaros (Figura 5) que apresentam um corpo bojudo, bordo semicircular, fundo plano e superfícies brunidas. Estes eram essencialmente utilizados para beber água. No entanto, surgem nos livros de receitas como unidades de medida (Casimiro e Newstead, 2019, p. 146).

Destaca-se um pequeno recipiente, cujo tamanho não permite atribuir funcionalidades, em cerâmica vermelha decorada com pequenas pedrinhas, nas quais surgem duas iniciais.

Sabe-se que a louça esmaltada era produzida $n$ e o forno da Mata da Machada a partir da década 20 do século XVI mas esta só se torna abundante nos contextos arqueológicos a partir de 1560 (Casimiro, 2013, p. 354). No conjunto de faiança da Silha do Alferes encontramos duas tipologias, taças carenadas e pratos.

Não nos é possível concluir se estas peças forma produzidas no vale do Tejo ou importadas do sul de Espanha. Contudo, a produção em Lisboa de louça revestida a branco encontra-se documentada arqueologicamente pelo menos desde os finais do século XV (Henriques et al., 2019, p. 920).

A acreditar que a louça esmaltada é maioritariamente produzida na zona do vale do Tejo, os objetos de importação são raros e oriundos de Sevilha, Veneza e China.

De Itália o centro produtor que mais abasteceu Portugal foi Montelupo. Na Silha do Alferes encontraram-se quatro fragmentos de pratos oriundos de Montelupo. Este tipo de cerâmica, sobretudo pratos e taças, caracteriza-se por ser bastante decorada recorrendo à policromia. Nos pratos encontramos decoração que podemos classificar de fiori centrale, spirali arancio e a blu grafito (Amaro et al., 2013, p. 1021) apresentando as cores laranja, azul, verde e amarelo. Este tipo de decoração é característica do século XVI (Amaro et al., 2013, p. 1021). 
As produções em Isabella Polychrome (Figura 6) têm sido identificados em diversas partes do país. O mesmo se pode dizer das peças vidradas a melado e decoradas com traços de manganês. Em 1996, no Largo Corpo Santo ao serem realizados trabalhos arqueológicos, foram encontrados fragmentos de pratos semelhantes aos da Silha do Alferes (Caroscio, 2015, p. 105).

A porcelana chinesa, como expectável, também aqui aparece, ainda que em quantidades mais reduzidas. A importação da porcelana encontra-se documentada a partir da primeira viagem de Vasco da Gama (Henriques, 2012, p. 920). A porcelana faz parte do grupo que se denomina de azul e branca que se desenvolveu na dinastia Ming e Qing (Gomes et al., 2013, p. 1059). Na Silha do Alferes encontraram-se quatro fragmentos de porcelana, um bordo com decoração geométrica e três fragmentos de bojo sendo que um apresenta decoração fitomórfica. Foram classificados como produções do período Zhendde e Jiajing. O número é na verdade reduzido para a quantidade que costuma aparecer nos contextos urbanos. Um único fragmento de vidros de Veneza, ou ao estilo de Veneza foi recuperado.

A cerâmica de armazenamento também tende em aparecer muitos nos contextos arqueológicos modernos (Figura 7). Deste grupo fazem parte os cântaros, as jarras, garrafas, bilhas e potes. Muitos destes objetos são designados ao armazenamento de água mas podiam também conter outros líquidos (Casimiro, 2020, p. 236).

Os cântaros caracterizam-se por ter um bordo semicircular ou extrovertido, um fundo plano, um corpo bojudo e duas asas equidistantes. A bilha caracteriza-se por ter só uma asa (Casimiro e Valongo, 2017, p. 1837). Os potes são recipientes bojudos, desprovidos de asas. As garrafas, jarras, jarros e bilhas são formas bojudas distinguindo-se pelo tipo de bordo e asa.

Surgiram ainda algumas malhas de jogo. Estes objetos em forma de disco, muitas vezes aproveitando fragmentos de outros recipientes são constantes nos contextos arqueológicos e poderiam ser utilizados em tabuleiros de madeira móveis ou desenhados diretamente sobre as mesas ou no chão ou bancadas e degraus de pedra (Fernandes, 2013).

\section{CONCLUSÃO}

Mesmo sem um método arqueológico e sem estratigrafia segura, o sítio arqueológico da Silha do Alferes não pode ser ignorado. Este é um sítio importante pois não só temos uma cronologia segura que nos é dada pelo material estudado e que está em excelente estado de conservação, mas é possível perceber a quem pertenciam aqueles terrenos. $\mathrm{O}$ conjunto de materiais permite concluir que apesar de a propriedade ser de um funcionário régio quem ali vivia possuía uma capacidade económica moderada. Os objetos maioritários correspondem a produções locais/ regionais da zona do Vale do Tejo. As importações são mínimas correspondem a achados isolados de cerâmica italiana, espanhola e chinesa que, à época, estavam a ser abundantemente utilizadas ou já mesmo descartadas noutros contextos arqueológicos. Esta não seria a zona principal de habitação daquela quinta, mas apenas a casa de um dos seus ocupantes, mostrando como viveriam as comunidades rurais nas quintas da margem sul no século XVI.

Mas a Silha do Alferes é também um sítio que foi pilhado e destruído antes de ser possível uma escavação com método científico. A importância deste local não pode ser recusada porque não há estratigrafia. A implementação do espaço na zona rural do Seixal, o conhecimento do seu proprietário e a coleção aqui encontrada não pode ser ignorada no estudo desta zona. Os contextos destruídos, por norma secundarizados nos estudos arqueológicos, devem ser considerados pelas informações que transmitem.

Este é assim um contexto doméstico importante para a arqueologia moderna, sobretudo por se encontrar na margem sul do Tejo, e a sul de Lisboa onde a arqueologia moderna se encontra mais desenvolvida.

Ao estudar o material encontrado sabemos que estamos perante uma ocupação doméstica e é possível compreender que tipo de objetos eram utilizados em ambientes domésticos no século XVI no Seixal. As peças de importação que foram encontradas são essenciais na compreensão das trocas comerciais que existiam com outros países e também são fundamentais para o enquadramento sócio-económico e com isso perceber qual a base social dos indivíduos que vivam na Quinta da Torre Queimada.

\section{AGRADECIMENTOS}

O meu mais sincero obrigada aos arqueólogos da Câmara Municipal do Seixal, nomeadamente o Jorge Raposo, o Cézer Neves e o José Henrique, bem como à Tânia Casimiro, minha orientadora de mestrado, por ter instigado esta publicação. 


\section{BIBLIOGRAFIA}

AMARO, Clementino; FILIPE, Vanessa; HENRIQUES, José; MANSO, Cláudia (2013) - Prisão do Aljube no século XVI vidros, majólica italiana e cerâmica esmaltada espanhola in: ARNAUT, José Morais; MARTINS, Andrea; NEVES, César. (eds.) Arqueologia em Portugal - 150 anos. Lisboa: Associação dos Arqueólogos Portugueses, pp. 1019-1024.

BARBOSA, Teresa; CASIMIRO, Tânia; MANAIA, Rodolfo (2009) - A late $15^{\text {th }}$ century household pottery group from Aveiro (Portugal). Medieval Ceramics, 30, pp. 119-136.

CAROSCIO, Marta (2015) - Jaúdenes 5: um contexto arqueológico de época portuguesa em Ceuta in TEIXEIRA, André; PAREDES, Fernando Villada; SILVA, Rodrigo Banha da (coord) Ciudad Autonoma de Ceuta. Câmara Municipal de Lisboa, pp. 169-211.

CASIMIRO, Tânia Manuel (2013) - Faiança portuguesa: datação e evolução crono-estilística, Revista Portuguesa de Arqueologia, 16. Lisboa: Direção- Geral do Património Cultural, pp. 351-367.

CASIMIRO, Tânia Manuel (2020) - Materialidades Quotidianas de Idade Moderna em Alhandra. Os contextos arqueológicos da escavação do Centro de Saúde, in Cira Arqueologia, número 7, Vila Franca de Xira: Museu Muncicipal Vila Franca de Xira, pp. 233-245.

CASIMIRO, Tânia Manuel; BOAVIDA, Carlos; DETRY Cleia (2017) - Cozinhar e comer: cerâmicas e alimentação em Carnide (1550-1650)", in Actas do Encontro Diz-me o que comes... Alimentação antes e depois da cidade, Lisboa, Centro Arqueologia de Lisboa, pp. 105-116.

CASIMIRO, Tânia Manuel; VALONGO António (2017) Uma lixeira nas casas nobres do infantado. In Arqueologia em Portugal, Lisboa, Associação dos Arqueólogos Portugueses, pp. 1835-1848.

CASIMIRO, Tânia Manuel; HENRIQUES, José Pedro; FILIPE, Vanessa; BOAVIDA, Carlos. (2018) - Lead glazed ceramics in Lisbon $\left(16^{\text {th }}-18^{\text {th }}\right.$ centuries), Lisboa: LNEC, pp. 268-282.

CASIMIRO, Tânia Manuel; NEWSTEAD, Sarah (2019) 400 Years of water consumption: early modern pottery cups from Portugal, Ophiussa, 3, pp. 125-133.

FELÍCIO, Catarina; SOUSA, Filipe; GUIMARÃES Raquel; GADANHO, André (2017) - A ceramic Italiana dos séculos XV e XVI do Largo do Jogo da Bola em Carnide, in Arqueologia em Portugal - 150 anos. Lisboa: Associação dos Arqueólogos Portugueses, pp. 1791-1802.

FERNANDES, Isabel; CARVALHO, Rafael. (2003) - A loiça seiscentista do Convento de São Francisco de Alferrara (Palmela), in Actas das 3 . $^{\text {as }}$ Jornadas de Cerâmica Medieval e Pós Medieval, Métodos e Resultados para o seu Estudo. Tondela: Câmara Municipal de Tondela, pp. 231-252.

FERNANDES, Lídia (2013) - Tabuleiros de Jogos inscritos na pedra 2013, Lisboa: Apenas Livros.
GOMES, Rosa Varela; GOMES, Mário Varela; ALMEIDA, Mariana; Boavida, Carlos; NEVES, Dário; HAMILTON, Kierstin; SANTOS, Carolina (2013) - Convento de Santana (Lisboa). Estudo preliminar do espólio da fossa 7", in: ARNAUD, José Morais; MARTINS, Andrea; NEVES, César (eds.), Arqueologia em Portugal - 150 anos, Lisboa, Associação dos Arqueólogos Portugueses, pp. 1057-1065.

HENRIQUES, José Pedro Vitém (2012) - Do Oriente para Ocidente: contributo para o conhecimento da porcelana chinesa nos quotidianos da época moderna. Estudo de três contextos arqueológicos de Lisboa. In TEIXEIRA, André; BETTENCOURT, José (coord.), Velhos e Novos Mundos: Estudo de Arqueologia Moderna. Lisboa: CHAM - FCSH/ NOVA-UAç, vol. 2, pp. 919-932.

HENRIQUES, José Pedro; FILIPE, Vanessa; CASIMIRO, Tânia Manuel; KRUS, Alexandra (2019) - Vestígios de produção oleira dos finais do século XV (Escadinhas da Barroca, Lisboa), in: Fragmentos de Arqueologia, Extrair e Produzir... Dos primeiros artefactos à Industrialização, Lisboa: Centro Arqueologia de Lisboa, pp. 108-120.

MCCLELLAND, Susana; JESUS, Luciana de; BAÇO, Joana; AVELINO, Andreia (2016) - Projeto integrado de requalificação do espaço público do Seixal - Relatório Preliminar.

RODRIGUES, D. (1821) - Arte de Cozinha dividida em quatro partes..., Lisboa: Na oficina da Viúva de Lino da Silva.

RODRIGUES, J. A. Severino; BOLILA, Catarina; FILIPE, Vanessa; HENRIQUES, José Pedro; RIBEIRO, Inês Alves; SIMÕES, Sara Teixeira (2013) - As cerâmicas da Idade Moderna da Fortaleza de Nossa Senhora da Luz, Cascais, in: TEIXERA, André e BETTENCOURT, José, (eds), Velhos e Novos Mundos. Estudos de Arqueologia Moderna, Lisboa, Centro de História de Além-Mar, pp. 865-876.

GOMES, Rosa Varela; CASIMIRO, Tânia Manuel; Neto, J. L. (2017) - Acerca do consumo do cuscuz na alimentação açoriana, Atlântida. Revista de Cultura, vol. LXII, pp. 2-12. 


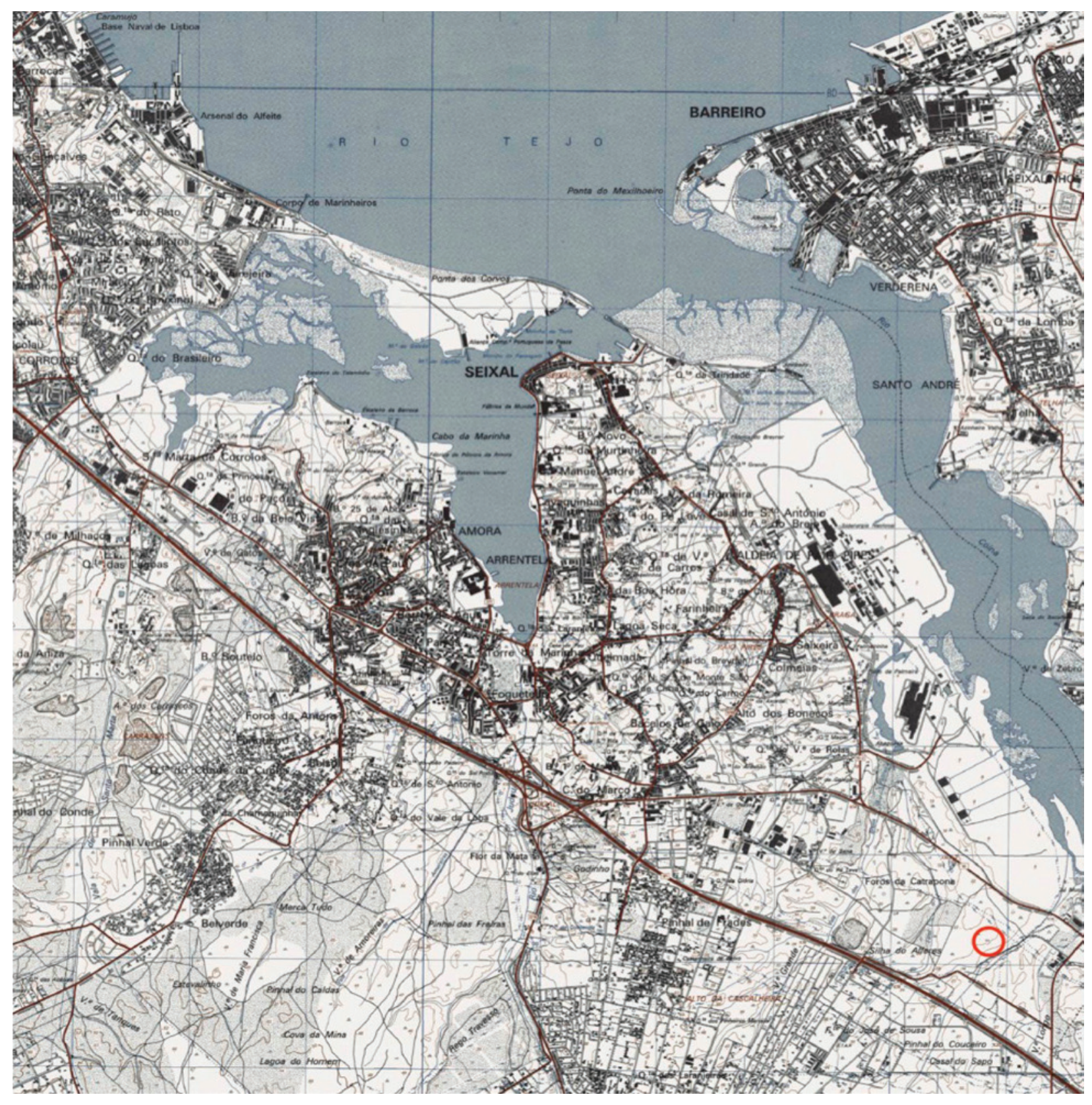

Figura 1 - Localização da Silha do Alferes. Carta Militar Seixal. 

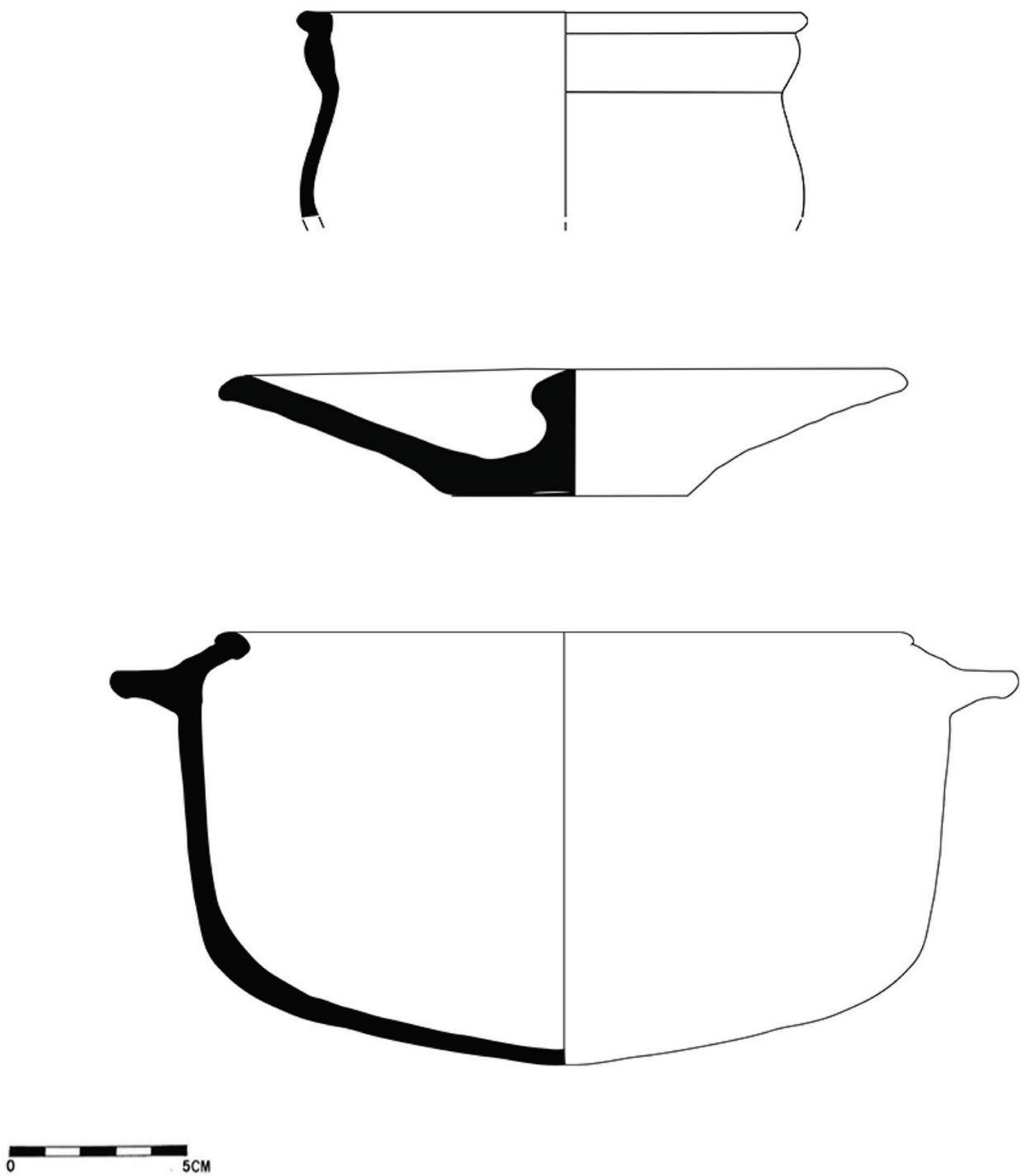

Figura 2 - Panela, Testo, Tacho. 


$$
\dot{I}
$$



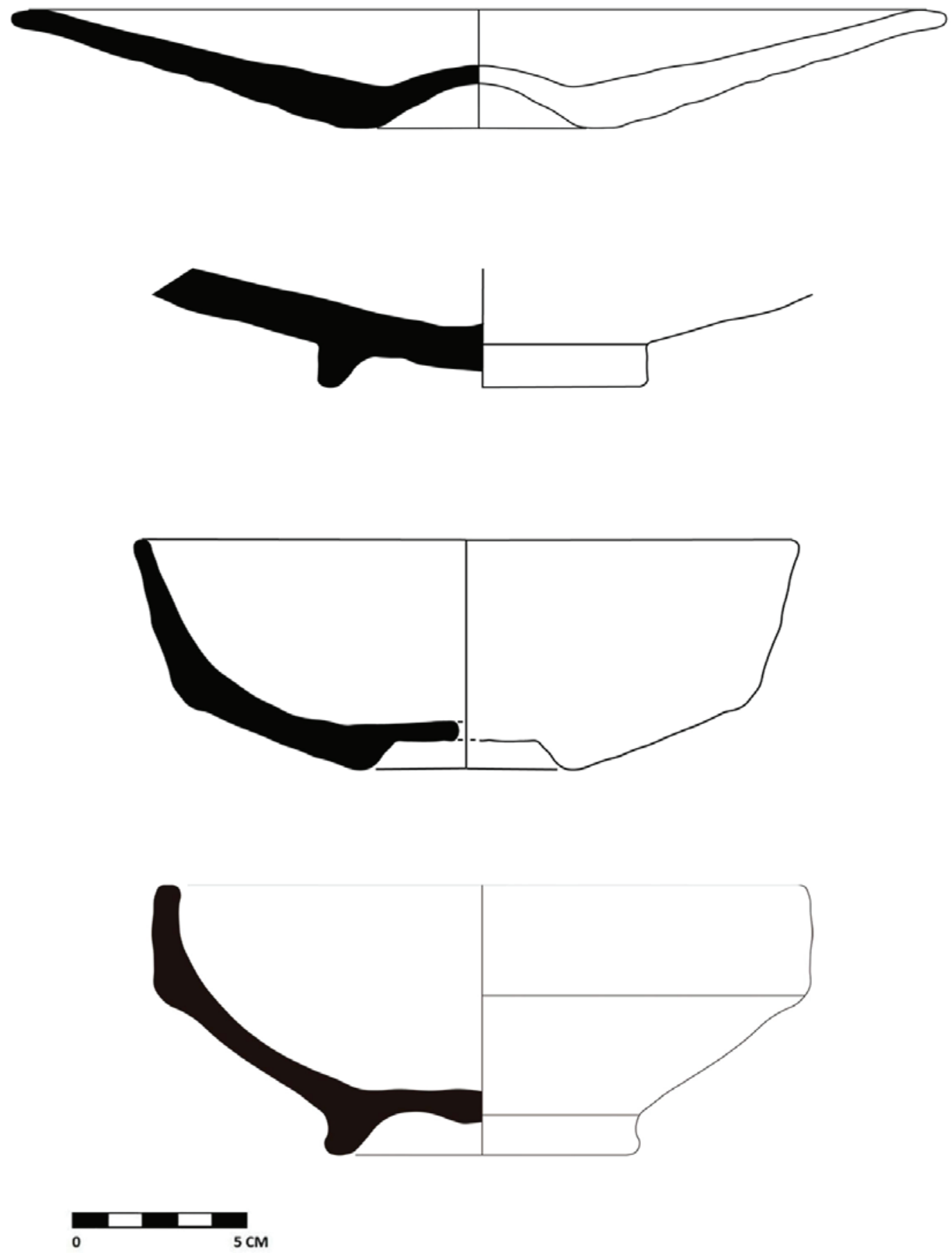

Figura 4-Pratos e Taças. 

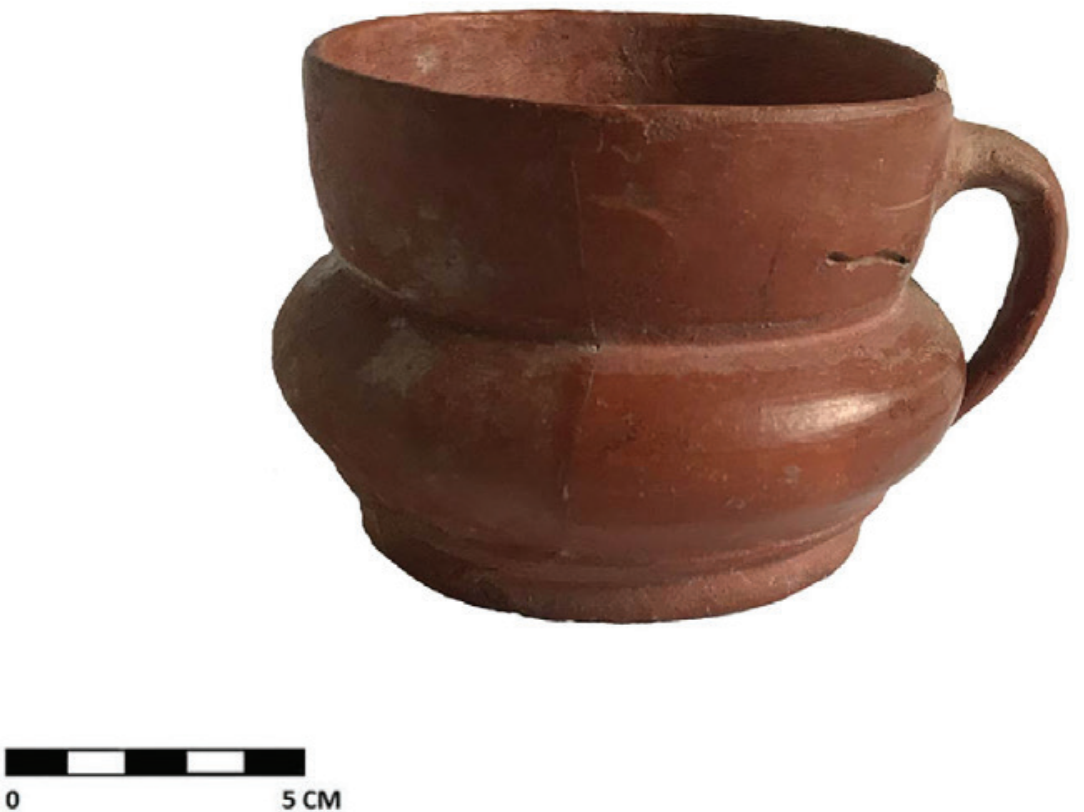

Figura 5-Púcaro.

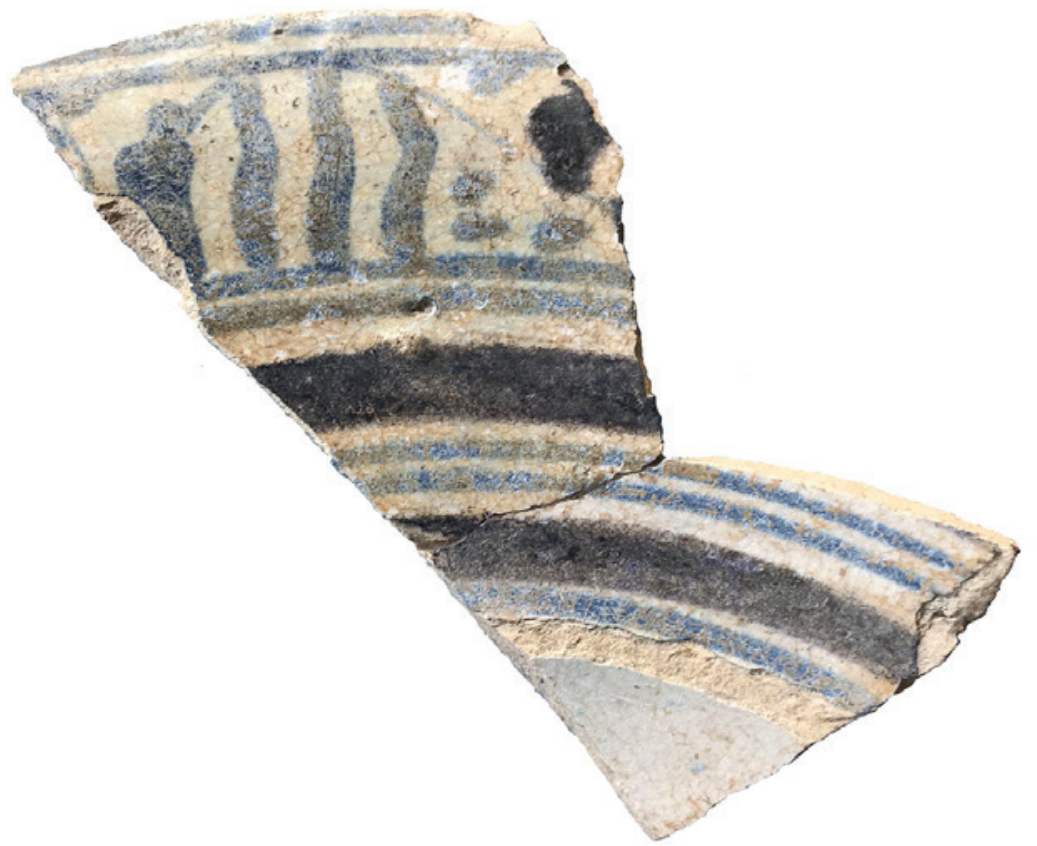

Figura 6 - Prato com decoração tipo Isabella Polychrome. 

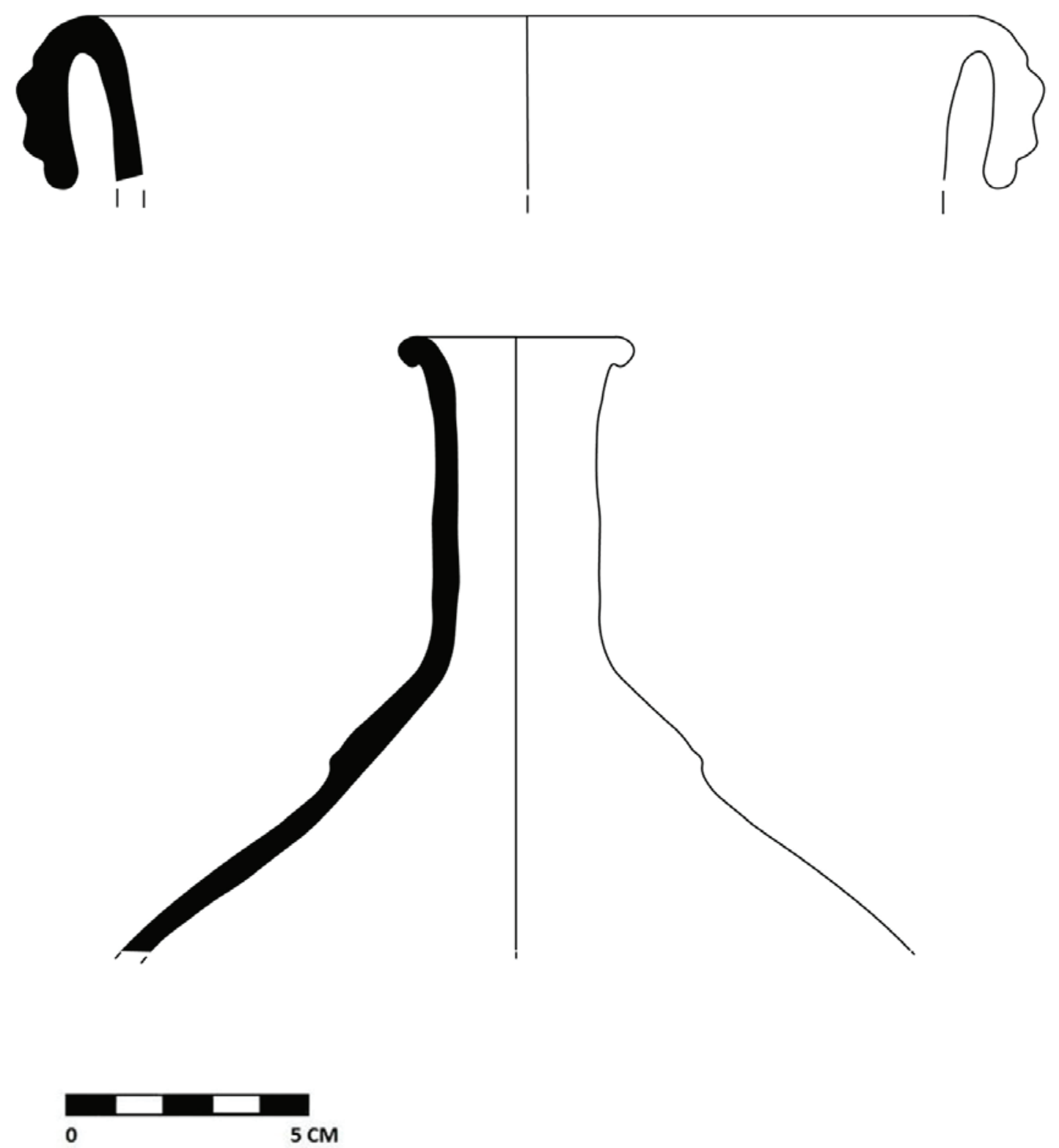

Figura 7-Cântaro, Garrafa. 


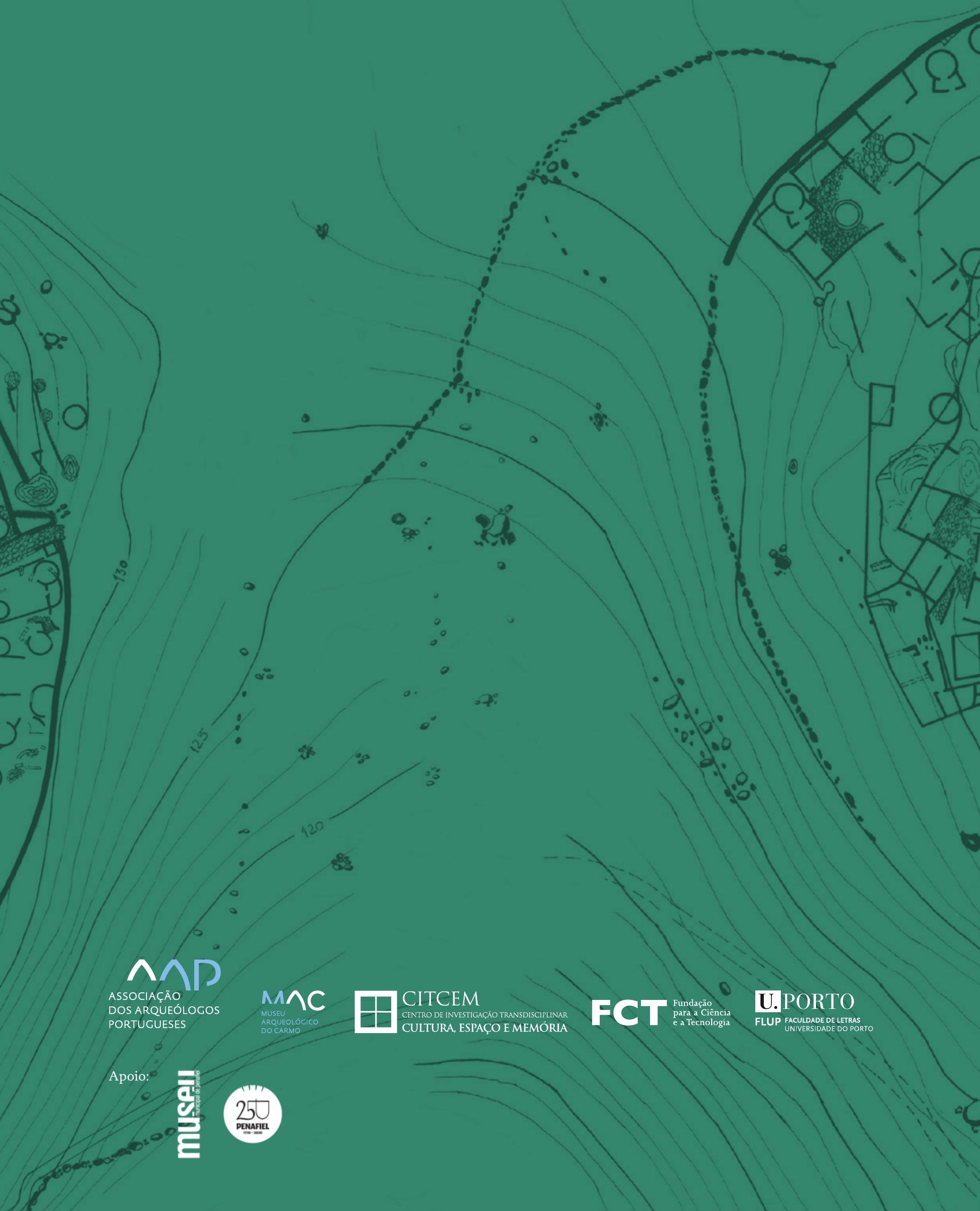

